Pamiętnik Literacki 2021, 3, s. 107-120

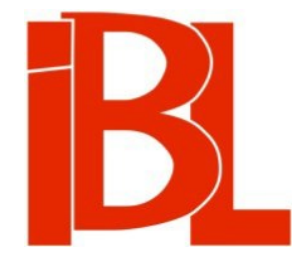

\title{
„Poezje” Cypriana Norwida z 1863 roku jako świadectwo autorecepcji
}

Elżbieta Dąbrowicz 
Pamiętnik Literacki CXII, 2021, z. 3, PL ISSN 0031-0514

DOI: $10.18318 / \mathrm{pl} .2021 .3 .6$

ELŻBIETA DĄBROWICZ Uniwersytet w Białymstoku

\section{„POEZJE” CYPRIANA NORWIDA Z 1863 ROKU JAKO ŚWIADECTWO AUTORECEPCJI}

We wstępie do Pism wszystkich Cypriana Norwida ledwie napomknął Juliusz Wiktor Gomulicki o Poezjach z 1863 roku, dając jednak wyraz przekonaniu o wysokiej wartości tomu ${ }^{1}$. Ocenę rzucił nawiasowo, demaskując mechanizm nieżyczliwej poecie „krytyki koteryjnej” ${ }^{2}$. Za sprawa jej milczenia - stwierdzał:

nie doczekawszy się po wydaniu Poezyj Norwida, stanowiących bez wątpienia jakiś przełomowy punkt w dziejach całej nowożytnej poezji polskiej, ani jednej recenzji - [lipski wydawca Brockhaus] zrezygnował w $1866 \mathrm{r}$. z ogłoszenia ich drugiego tomu, jeszcze bardziej rewelacyjnego aniżeli poprzedni ${ }^{3}$.

Sformułowanie ,jakiś przełomowy punkt” wydaje się niespójne logicznie: skoro ,jakiś”, to raczej nie „przełomowy”. Przełom zakłada przecież zmianę spektakularną, bez dwóch zdań. Po namyśle przychodzi wszelako skonstatować, że Gomulickiego nie tyle zawiodło wyczucie językowe, ile wypowiedział on dwie kwestie naraz: przełomu de facto nie było, bo nikt w latach sześćdziesiątych XIX wieku Norwidowskiego zbioru nie uznał za wydarzenie literackie, ale kiedy się patrzy już z perspektywy XX-wiecznej, „przełomowość” nie podlega dyskusji: wszak Zenon Przesmycki przejął się twórczością Norwida właśnie dzięki lekturze utworów zgromadzonych w lipskiej książce.

Rzucona nawiasem uwaga o Poezjach nie została we wstępie rozwinięta, a koncepcja edytorska zrealizowana w 11-tomowej edycji nie sprzyjała zastanawianiu się nad lipskim wydaniem jako dziełem autorskim. W całościowym opus z lat 1971-1976, podobnie jak w nieukończonych przez Przesmyckiego Pismach zebra-

1 Tom ukazał się w listopadzie 1862, ale $\mathrm{z}$ datą: 1863. 18 XII pisano do C. Norwida $\mathrm{z}$ Lipska, informując o przekazaniu Poezji do sprzedaży kilka tygodni wstecz. Zob. Z. Trojanowiczowa, E. Lij e w s k a (przy współudz. M. Plut y), Kalendarz życia i twórczości Cypriana Norwida. T. 2. Poznań 2007, s. 107.

2 J. W. Gomulicki, wstęp w: C. Norwid, Pisma wszystkie. T. 1: Wiersze. Cz. 1. Zebrał, tekst ustalił, wstępem i uwagami krytycznymi opatrzył J. W. Gomulicki. Warszawa 1971, s. XIII. „Koteryjność” życia literackiego nie tylko Norwidowi szkodziła. W „Przeglądzie Poznańskim” z 1863 roku (t. 35, s. 185) czytamy o typowych dla polskiej prasy „taktykach milczenia” wobec znaczących publikacji, które nie zgadzały się $z$,wyobrażeniami” propagowanymi na łamach poszczególnych tytułów, i „podnoszenia wysoko lada nędzoty odtwarzającej zdawkowe, w ich kole popłacające zdania".

3 G o m u licki, op. cit., s. XIV. Brak recenzji nie był powodem zrezygnowania wydawnictwa $z$ dalszej współpracy z Norwidem (badacze zwykle upatrują przyczyn w niesprzyjającej sytuacji międzynarodowej - konflikcie prusko-austriackim z 1866 roku). 
nych i Wszystkich pismach, chodziło bowiem o udostępnienie Norwidowej spuścizny, której większą część wydobyto z manuskryptów po śmierci poety. Obaj edytorzy podkreślali niezwykłość tego przypadku i nietypowość stojącego przed nimi zadania ${ }^{4}$. Ilościowa przewaga dorobku rękopiśmiennego nad drukowanym skłoniła ich do niwelowania różnicy między utworami wydanymi za życia autora a zachowanymi w brulionach do czasu ich pośmiertnego udostępnienia. Wszystkie poniekąd sprowadzali do formy rękopiśmiennej, Norwida zaś postrzegali jako zabłąkanego w XIX-wieczne realia „człowieka jutra”

Uprzywilejowanie manuskryptu sprawiło, że mimo wysokiej oceny lipskiego wydania Poezji Gomulicki nie zachował jego układu w Pismach wszystkich. Zdecydował się pójść w ślady Przesmyckiego, który ewentualność przedruku zawartości tomu z 1863 roku kategorycznie odrzucił:

Nie widzieliśmy natomiast możliwości ani powodu zachowania w niepodzielnej i niezmiennej całości tomu Brockhausowskiego, jako raczej antologicznego, a pod względem chronologii, zwłaszcza w części lirycznej, nazbyt bezładnego. [...] Nie tyle dbał w nim [Norwid] - rzecz prosta, o następstwo chronologiczne, ile o przedstawienie wszystkich rodzajów i typów swojej twórczości. Weszły tu zatem nie tylko poezje, lecz i dramat, i proza epicka (legendy i nowele), i nawet proza dydaktyczna (O sztuce dla Polaków). Materiał ten cały musieliśmy rozbić, wszystko poza liryką i epiką powydzielać do odpowiednich tomów naszej edycji, w pozostałych zaś działach pism wierszem uporządkować następstwo w czasie ${ }^{6}$.

Jak widać, Przesmyckiemu nie brakowało argumentów, by zawartość Poezji rozdysponować wedle własnego planu. Uznał lipski tom za antologię, prezentująca możliwości pisarskie Norwida wedle klucza gatunkowego, nie za osobne dzieło autorskie. Przeszkadzał też Miriamowi achronologiczny układ treści w Poezjach, choć edytor sam przecież widział konieczność odstępstw od chronologii, by unaocznić całości „projektowane”, lecz nie wydane przez poetę ${ }^{7}$. Domniemywał ponadto, że ponieważ oferta $z$ Lipska przyszła niespodziewanie (Norwid poczatkowo planował wydrukować tam jedynie Krakusa), zawartość tomu kompletowana była

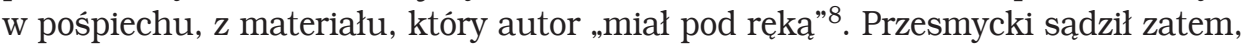

4 Zob. ibidem, s. VII. Gomulicki szacował, że 2/3 utworów (nie licząc listów, notatników etc.) w wydaniu stanowiły „pisma pośmiertne”. O Gomulickim jako edytorze wypowiada się P. Chle bows ki w artykule „Wszystkość nadciaga”. O Gomulickiego edycji kompletnej „Pism” Norwida - kilka uwag („Białostockie Studia Literaturoznawcze” 2019, nr 14).

5 Z. Przesmycki (Miriam), Uwagi wstępne. (Pism wierszem dziat pierwszy). W: Wybór pism krytycznych. Oprac. E. Korzeniew ska. T. 2. Kraków 1967, s. 261.

6 Ibidem, s. 272.

7 Zob. ibidem, s. 271.

8 Zob. ibidem. Innego rodzaju obiekcje wobec edycji Brockhausa formułowała J. Ru d nick a (Jak Brockhaus wydawał Norwida. „Studia Norwidiana” t. 8 〈1990〉), zestawiając teksty wydrukowane w Poezjach z zachowanymi autografami. Z porównania tego wynikało, że Norwid nie zrobił ostatniej korekty, lecz scedował ją na wydawnictwo, czyli na E. Ł. Kasprowicza. Podobne obserwacje poczyniła wcześniej J. P u zy n in a (Stowo Norwida. Wrocław 1990, s. 26-27) w odniesieniu do tekstu Dwóch męczeństw. Według umowy zawartej z pisarzem wydawnictwo zobowiązywało się, co prawda, do niewprowadzania zmian w tekstach oraz ich układzie, a także do sukcesywnego przekazywania ich do autorskiej korekty. Rudnicka przypuszczała, że tarapaty finansowe skłoniły poetę do darowania sobie pracy nad korektą. Nie sądziła natomiast, by wydawnictwo ingerowało również w kompozycję zbioru. Dodam, iż byłoby to dalekie od stylu zachowań Norwida, gdyby nie skomentował on zbytniej samowoli edytora, w razie gdyby takiej się dopuszczono. 
iż presja czasu mocno ograniczyła Norwidowi pole do pracy koncepcyjnej. W okolicznościach bardziej sprzyjających - dawał do zrozumienia - powstałaby całość zupełnie inna. Co ciekawe jednak, chociaż edytor zrezygnował $\mathrm{z}$ uszanowania integralności Poezji, zainspirował się ich układem, komponując tom A Pism zebranych:

Same natomiast działy, mniej lub więcej wyraźnie zaznaczone, sam sposób klasyfikacji i grupowania utworów przejęliśmy i zastosowali w tomie A jako z jednej strony, wyraz architektonicznych intencji poety, $z$ drugiej zaś, jako ułatwiające orientację uwydatnienie kilku równoległych w nim, od r. 1847 do 1863, prądów twórczych. Tak powstały: Krag ideowy, reprezentowany naczelnie w tomie Brockhausowskim przez Pięć zarysów i broszurę o sztuce, a obejmujący u nas wszystkie zebrane poematy, w których poeta wyraził swe poglądy filozoficzne, estetyczne, społeczne i polityczne; Krag liryczny i okolicznościowy, którego nazwę nawet przejęliśmy wprost z Poezyj lipskich; wreszcie Krag „Quidama”, uwydatniony tam wyraźnie przez samego poetę w pewnych ugrupowaniach końcowych, a skupiajacy u nas wszystkie rzeczy osnute na tle tych koniunkcji cywilizacji starożytnej z chrześcijańską, które, przez połączenie elementów plastycznych, ideowych i mistyczno-uczuciowych, specjalnie zawsze pociągały Norwida ${ }^{9}$.

Przesmycki zaniechał więc przedruku Poezji, ale ich „architekturę” zastosował do większej liczby tekstów, nadając intencji autorskiej wyższą sankcję porządkującą. Nie zgodził się, żeby potraktować tom lipski jako przemyślaną całość, pochylając się równocześnie $\mathrm{z}$ pietyzmem nad dziełami w fazie projektu.

Obydwaj edytorzy odmówili wydaniu Brockhausowskiemu statusu dzieła, bo i nie jest to powód błahy - komplikowało im pracę nad scalaniem spuścizny Norwida. Ich decyzje odnośnie do naruszenia integralności Poezji nie były w żadnym razie pochopne, ale i niebezkosztowe. $Z$ pola widzenia czytelników Pism zebranych oraz Pism wszystkich usunęli tym sposobem najobszerniejszy tekst wydany za życia Norwida i przezeń autoryzowany ${ }^{10}$. W konsekwencji na znaczeniu zyskało Vade-mecum, choć zdefektowane i w wielu miejscach dyskusyjne co do rekonstrukcji woli autora. Zaaranżowany przez norwidologów tryumf Vade-mecum po śmierci autora przyćmił sukces publikacyjny jego Poezji, sukces polegajacy na tym, że w ciagu miesiąca udało się Norwidowi wstępnie przygotować do druku pokaźnych rozmiarów tom o zawartości, która pozwalała określić stanowisko poety na tle tradycji literackiej i wobec zagadnień aktualnych ${ }^{11}$. Brak reakcji ze strony krytyków literackich na edycję lipska zapewne ułatwił Przesmyckiemu i Gomulickiemu jej zmarginalizowanie: skoro Poezje przeszły niedostrzeżenie, to w gruncie rzeczy nie zaistniały publicznie ${ }^{12}$. Jednak $\mathrm{z}$ mojego punktu widzenia publikacja nieporówny-

Przesmycki (Miriam), op. cit., s. 272-273.

Kwestia autoryzacji przez Norwida została upubliczniona już w 1862 roku, w związku z wymianą myśli na łamach lwowskiego „Dziennika Literackiego” (nr 42), w artykule Rozprawa z księgarzem lipskim, odnośnie do zarzutów pod adresem wydawnictwa Brockhausa o bezprawne przedruki.

Dnia 5 II 1862 z oficyny Brockhausa wyszła propozycja opublikowania tomu Poezji Norwida, pod koniec marca rękopis trafił do Lipska. Zob. Trojanowiczowa, Lijewska, op. cit., s. 64. W parę dni później poeta dosłał jeszcze kilka wierszy. Wtedy też zapewne przypomniał wydawcy, by drukowano wszystko bez zmian i w autorskim układzie (ibidem, s. 73).

Na Poezje warto by spojrzeć przez pryzmat niegdysiejszych rozważań J. Sła wiń s ki e go (Krytyka jako przedmiot badań historycznoliterackich. W zb.: Badania nad krytyka literacka. Red. ... Wrocław 1974, s. 16-17) o definicji "faktu literackiego”. Tomów Brockhausowskiej serii z reguły nie recenzowano. Na łamach „Przeglądu Poznańskiego” (ukazywał się do 1865 roku włącznie) żaden Z nich nie został poddany ocenie. W lwowskim „Dzienniku Literackim” (1861, nr 42, s. 308; 1862 , 
walna z poprzednimi pod względem rozmiarów i rozpiętości problemowej, w dodatku przypadająca w połowie, jak się miało okazać, drogi pisarskiej Norwida, chociaż nie wzbudziła zainteresowania odbiorców, przedstawia nieocenioną wartość poznawczą jako wydarzenie pierwszorzędnej wagi w jego biografii twórczej: Norwid awansuje na autora Poezji w oczach własnych i cudzych ${ }^{13}$.

Ale rzecz nie sprowadza się wyłącznie do operacji wizerunkowej. Poezje, scalające dorobek $\mathrm{z}$ kilku lat, są efektem szczególnego rodzaju doświadczenia pisarskiego, a zarazem świadectwem autorecepcji ${ }^{14}$. Intensywna, pomyślnie zakończona praca podziałała też niewatpliwie niczym impuls twórczy, stymulujący kolejne poczynania artystyczne. Czytając i redagując dzień po dniu wiele stronic przez siebie napisanych, Norwid miał wyjątkową okazję do pogłębionego obcowania z samym soba jako autorem, do kontaktu $z$ własnym stylem, do rozpoznania jego wyróżników. Uzyskał także możliwość, by zobaczyć każdy z tekstów opracowywanych z myślą o druku wśród innych o tym samym przeznaczeniu, zapewne odkrywając wcześniej nieoczywiste związki między nimi. „Architektura” tomu, która tak silnie przemówiła do Przesmyckiego, byłaby więc efektem konfrontacji autora $z$ własna twórczością. Stwierdzenie Miriama, że Poezje, złożone z tekstów, które pisarz miał akurat $\mathrm{w}$ bezpośrednim zasięgu, nie stanowią całości godnej utrwalenia, łatwo obrócić również na ich korzyść. Norwid dysponował bowiem przede wszystkim literackim materiałem z końcówki lat pięćdziesiątych i z 1861 roku. Jedynie cykl Pięć zarysów powstał między 1847 a 1852 rokiem, co zresztą nie przydaje mu osobnego kolorytu. Uwaga $z$ wiersza Rzeczywistość, oznaczonego datą: 1847, o młodości upływającej na „czytaniu / Telegraficznych depesz o różnym powstaniu [...]” i o rachubie „Od ostatnich do tylko co zaszłych wypadków [...]” (DW-4 149) ${ }^{15}$, stosuje się także do lat nieco późniejszych. Prasa, niezależnie od miejsca wydawania i języka, wciąż donosiła wtedy o czasie przejścia i zamętu, z którego wyłoni się

$\mathrm{nr} 9$, s. 72) odnotowano tom 6 , przy 7 nieco obszerniej przedstawiano intencje wydawcy. W numerze 7 z 1863 roku zaanonsowano Poezje Norwida. W „Bibliotece Warszawskiej” (t. 1, s. 196) poinformowano o wydaniu Norwidowych Poezji oraz zapowiedziano kolejne pozycje. Proponowano też, jakie powinny jeszcze zostać uwzględnione w serii. Stąd wniosek, że prasa wywoływała zainteresowanie serią, nie zaś jej poszczególnymi elementami.

13 W nekrologach pisano o Norwidzie jako o autorze dzieł drukowanych, w tym właśnie tomu lipskiego. Na edytorskim usunięciu Poezji z pola uwagi publicznej wiele traci nie tylko Norwid, ale też obraz historii literatury późnego romantyzmu. Traktując Poezje jako dzieło, mamy szansę obraz ten zmodyfikować. O Poezjach w kontekście późnoromantycznym pisałam w artykule Pożegnania $z$ romantyzmem. 1859-1863 (w zb.: Literatura $i$ kultura lat 60. XIX wieku między polityka a prywatnościa. Dyslokacje. Red. U. Kowalczu k, D. W. Maku ch, D. M. O siń ski. Warszawa 2019). O autorecepcji tak pisał E. Balc erzan (Literackość. Modele, gradacje, eksperymenty. Torun 2013, s. 170): „Z autorecepcja mamy do czynienia wtedy, gdy literatura rozpoznaje sama siebie w strukturach swoich własnych dzieł i za pomocą tych samych środków, jakie jej służą równocześnie do wielu innych celów czy efektów". Sporo uwagi poświęcił procesom autokomunikacyjnym, odnoszącym się do utworów in statu nascendi. Nie uwzględnił jednak sytuacji, kiedy one poniekąd rodzą się ponownie, gdy pisarz włącza je do nowej całości.

15 Skrótem DW odsyłam do Dzieł wszystkich C. No r wid a: DW-4 = t. 4: Poematy. 2. Oprac. S. S awi cki, P. Ch1 eb owski. Lublin-Warszawa 2011; DW-11 = Listy. 2. Przekł. W. Kwiat k ow ski, Sz. Babiński. Oprac. J. Rudni cka. 2016. Po skrócie podaję, po dywizie, numer tomu, a następnie stronice. Wyjątkowo $\mathrm{w}$ funkcji podkreślenia $\mathrm{w}$ cytatach $\mathrm{z}$ tego wydania pozostawiam kursywę, którą wprowadzili jego edytorzy. 
jakiś nowy ład czy nieład - polityczny, społeczny, moralny. Wojna krymska odsłoniła anachroniczność systemu rosyjskiego, wymuszając reformy, dojrzewała idea zjednoczenia Włoch, które skutkowało konfliktem między papieżem a ruchem narodowym, w Stanach Zjednoczonych Ameryki nabrzmiewały problemy na tle niewolnictwa, wywołując wojnę domowa, Chiny stanęły otworem dla ekspansji europejskiej... Wobec obfitości produkcji literackiej i większej jej dostępności (prasa, tanie serie wydawnicze) intensywnie zastanawiano się również nad misją literatury i powołaniem pisarza. $\mathrm{W}$ polskim piśmiennictwie komentowano dogasanie romantyzmu, ale też i jego życie pozagrobowe. Mniej krytycznie aniżeli w pierwszej połowie XIX wieku oceniano klasycyzm porozbiorowy ${ }^{16}$.

W Poezjach Norwida, traktowanych jako całość, nad sprawami polskimi wyraźnie dominuja zagadnienia odnoszące się do „ludzkości chrześcijańskiej”. Tych pierwszych zresztą nigdy nie rozważa się w izolacji od drugich. Analogicznie rozegrana została też relacja między odległa przeszłością a teraźniejszością. Zarówno w Quidamie z fabuła osadzona za panowania cesarza Hadriana, jak i w wierszach „okolicznościowych” ${ }^{17}$, poświęconych opisywanym w gazetach bohaterom teraźniejszości - emirowi Abd el-Kaderowi, Johnowi Brownowi, papieżowi Piusowi IX, „Żydom polskim” - niepokoją te same pytania o kierunek, w jakim zmierza świat, i o busolę etyczną, która pomagałaby w dokonywaniu wyborów życiowych. Ponieważ wymienione ujęcia dają się zaobserwować w Poezjach, nie zaś tylko w pojedynczych utworach „zbiorowego wydania”, mogą być odtąd postrzegane jako cechy Norwidowego stylu. Należy do nich także wielogłosowość wypowiedzi literackiej, z która czytelnik ma do czynienia od wstępnych Prób poczynając, a na Polce kończąc ${ }^{18}$.

\section{Zarządzanie karierą}

Jeśli rozpatruje się przebieg kariery artystycznej Norwida w zestawieniu $z$,wielkoludami” romantycznymi i twórcami rówieśnymi ${ }^{19}$, przychodzi zauważyć, że nie spieszyło mu się do obszerniejszej prezentacji swego dorobku literackiego. Trudno w poczynaniach autorskich poety, $\mathrm{z}$ lat czterdziestych i pięćdziesiatych XIX wieku, rozpoznać posunięcia, które wskazywałyby na budowanie pisarskiego wizerunku i prestiżu wedle praktykowanych ówcześnie zasad. Adam Mickiewicz zadebiutował

Widać to w prasowych reakcjach na śmierć K. Koźmiana w 1856 roku.

W skład Poezji wchodził zbiór pt. Harfa, czyli liryczna i okolicznościowa część poezyj.

Wskazane tu wyróżniki stylu myślenia Norwida badacze jego twórczości opisywali już po wielekroć, nie wiążąc ich jednak $z$ wydaniem Poezji jako kluczowym momentem w procesie samookreślenia autorskiego.

Pisząc o karierze, mam na myśli jej tradycyjne rozumienie - jako strukturalnej własności organizacji bądź profesji czy, ogólniej mówiąc, jako zjawiska społecznego - oraz nowsze, które uwzględnia subiektywne aspekty kariery. W pierwszym - akcent pada na zależność wyobrażeń o karierze od wartości uznawanych w społeczeństwie. W drugim zakłada się niepowtarzalność kariery, która tworzy sekwencję jednostkowych aktywności, postaw, zachowań w życiu zawodowym. Teoretycy kariery w ujęciu podmiotowym uwzględniają wpływ doświadczeń związanych z praca zawodową na holistycznie traktowana jakość życia jednostki. Zob. A. Cybal-Mi chalska, Kariera jako „własność” jednostki - rozważania teoretyczne nad definicyjnym credo. „Kultura. Społeczeństwo. Edukacja” 2012, nr 1, s. 193-197. 
prasową publikacją Zimy miejskiej w 1818 roku, a już w latach 1822-1823 pokazał się jako autor dwóch tomów Poezji o zróżnicowanej gatunkowo zawartości. Juliusz Słowacki zadebiutował w 1830 roku Hugonem, w pierwszych zaś latach paryskich wydał aż trzy tomy Poezji. Widać tu, że obaj wymienieni twórcy starali się jak najszybciej wylegitymować publikacjami o tytułach jednoznacznie odsyłających do ich statusu poety. Poezje pełniły funkcję cokołu, na którym dumnie stawał autor-poeta. $Z$ kolei Teofil Lenartowicz, bliski metrykalnie Norwidowi, zadbał o skojarzenie swego nazwiska $z$ bardziej skonkretyzowanymi tytułami utworów. Wydał najpierw dwa tomiki Polskiej ziemi (w obrazkach) (1848), po czym zabieg ten powtórzył, ogłaszając Lirenkę w 1855 roku, a w roku 1859 - Nowa lirenkę. Z tymi dwoma ostatnimi zbiorami udało się Lenartowiczowi też na zawsze powiązać własną osobę, co skutkowało upowszechnieniem się apozycji „autor Lirenki”20. Tytuły pierwszych jego zbiorów wskazywały na duchowy patronat Wincentego Pola jako twórcy Pieśni o ziemi naszej. Szczęśliwy pomysł na siebie miał i sam Pol, zaczynając drogę literacką Pieśniami Janusza ${ }^{21}$.

Zważywszy na przychylny odbiór wierszy z okresu warszawskiego, Norwidowi powinno było zależeć na szybkim skompletowaniu utworów o zbliżonym charakterze w książce autorskiej. Narcyza Żmichowska, podobnie jak on zaliczana w latach czterdziestych XIX wieku do młodych talentów, już w roku 1845 zebrała swój dotychczasowy dorobek w pierwszym tomie Wolnych chwil Gabrieli, który na długi czas ukonstytuował jej tożsamość pisarską. Warszawski „cygan”, Seweryn Fillebron, zdobył się na wydanie Poezji w 1847 roku, ze wstępem „początkowego poety”, świadomego swoich ograniczen, ale przekonanego o doniosłości społecznej tworzenia wierszy, nawet nie najwyższego lotu ${ }^{22}$.

W zestawieniu z podanymi przykładami „zarządzania karierą” wybory Norwida nie tłumaczą się jasno. Czy dlatego nie zabiegał o szybkie wydanie tomiku autorskiego, że najpierw wiązał swoją drogę życiową raczej ze sztuką niż z literaturą? Jego Poezje ukazały się dopiero po 20 , z małym okładem, latach aktywności w dziedzinie literackiej i bardziej za sprawą szczęśliwego trafu niż metodycznej realizacji planów artystycznych. Utwory większych rozmiarów publikowane przezeń między debiutem a "pierwszym wydaniem zbiorowym” wyglądały na wywołane okolicznościami: Pieśni społecznej cztery stron, ukazała się w Poznaniu w 1849 roku z data w podtytule: 1848; Zwolon, wydrukowany tamże w 1851 roku, zdaniem Norwida, z winy księgarza zbyt późno, bo „monologia” pisana była „słowem prędkiem [...]. / Przy łunach, które tu i ówdzie błysły"23; Promethidion w tym samym roku, w Pary-

Z czasem Lirenka dała też asumpt do metaforycznego określania T. Lenartowicza mianem „lirnika mazowieckiego". Zob. m.in. A. J. Mi kuls k i, Lirnik mazowiecki. Teofil Lenartowicz i jego utwory. Lwów 1906. - H. Bi e g e l e is e n, Lirnik mazowiecki. Jego życie i dzieła. W świetle nieznanej korespondencyi poety. Warszawa-Lublin-Łódź 1913.

21 Nie mógł W. Polowi wybaczyć odstępstwa od stylu i hierarchii wartości J. K. Uj ej ski w swoim oskarżycielskim „liście spod Lwowa”: O Januszu i Panu Wincentym Polu, z 1860 roku.

22 S. G. Fillebro n, Poezje. Warszawa 1847, s. VII. Podobnie jak Norwid z wydaniem zbiorowym ociagał się R. Zmor s ki, jego Poezje ukazały się dopiero w Lipsku, w 1866 roku, u Brockhausa. W krótkim słowie wstępnym autor informował, że czyni zadość naleganiom, by zebrać „rozproszone poezje" (ibidem, s. V).

C. N orwi d, Zwolon. (Monologia). W: Pisma wszystkie, t. 4: Dramaty, cz. 1, s. 31. 
żu, z pytaniem skierowanym pod własnym adresem: „Gorzką taką pracę dlaczegożeś przedsięwziął?..." (DW-4 98). Z Czarnych kwiatów wynika, że proza ułożyła się w całość pod wpływem śmierci Paula Delaroche’a w 1856 roku, a więc w roku publikacji cyklu.

Nie widać tu starań o uwypuklenie rysów tożsamości autorskiej. Działań, które winny mieć na celu konstruowanie siebie jako autora na sprawdzona modłę, należałoby się dopatrzeć wyłącznie w tytułach Zwolon i Promethidion, kojarzących się nieuchronnie $z$ Irydionem Zygmunta Krasińskiego. Trzeba przy tym pamiętać, że on sam - co do przebiegu pisarskiej kariery - był przypadkiem jedynym w swoim rodzaju: przez lata realizował koncepcję anonimowego autorstwa, rezygnując z tradycyjnie pojętej sławy ${ }^{24}$. Ponieważ zaś Krasiński zaprzeczał, jakoby spod jego pióra wyszły kolejne dzieła, dopiero po śmierci poety dało się pomyśleć o ich zebraniu i wydaniu imiennym. Czy stosunek do własnej twórczości autora Irydiona nie zaważył na Norwidowej niechęci do podejmowania starań o scalanie swego dorobku? Dość, że gdyby nie inicjatywa Antoniego Zaleskiego, zaprzyjaźnionego z Norwidem jeszcze w latach czterdziestych XIX wieku żmudzkiego szlachcica, który latem 1858 zgłosił się do niego z projektem zebrania rozproszonych pism w książkowej edycji, on sam może nawet żadnych kroków w tej sprawie by nie poczynił ${ }^{25}$. Przychodzi też na myśl, iż właśnie te zakończone fiaskiem przymiarki do wspomnianej idei pozwoliły Norwidowi skutecznie zareagować na propozycję Brockhausa. Nieoczekiwana oferta $z$ Lipska padła na grunt przygotowany krzątaniną wokół poprzednich widoków na edycję zbiorową.

\section{Owocne fiasko}

Ślady niedopełnionej przyjacielskiej inicjatywy zachowały się w listach. Zaleski postanowił wydać własnym sumptem dzieło kolegi i wspomóc go kwotą z ewentualnej sprzedaży ${ }^{26}$. Pomysłu nie udało się zrealizować, ale propozycja Zaleskiego stworzyła Norwidowi okazję do obejrzenia się za siebie, skatalogowania tytułów i miejsc publikacji, do przypomnienia sobie o zalegających utworach przesłanych do druku, lecz niewydanych, albo też do sformułowania kilku myśli na temat własnego dorobku literackiego i pozycji społecznej pisarza. Powtarza się w listach do korespondentów uwaga odnośnie do rozproszenia własnej, wieloletniej już twórczości na łamach licznych tytułów prasowych: „po latach blisko dwudziestu rozrzucania pism moich po wszystkich dziennikach ojczystych [...]”, „poezje moje przez lat przeszło dziesiątek po wszystkich pismach polskich zamieszczane [...]”, „poezje moje porozrzucane od lat tylu [...]”, „moje poezje, od lat około dwóch dziesiątek rozrzucane po wszystkich dziennikach [...]”, „moje pisma od lat kilkunastu we

Zob. E. D ą brow i z, Romantyzm ziemi przechodów. Próby terytorialnej historii literatury. Białystok 2019, rozdz.: Poeta infamis.

W okresie między inicjatywą A. Zaleskiego a ofertą Brockhausa przymierzył się Norwid do „pism” czy „dzieł”, które miał wydać W. Pomian Zakrzewski. Zob. wiersz List do Walentego Pomiana Z., napisany w 1859 roku, opatrzony później notką: „Zwierzając mu rękopisma, następnie w XXI tomie B. P. P. wyszłe” („Chimera” t. $1\langle 1901\rangle$, z. 2, s. 185).

A. Zaleski, list do J. I. Kraszewskiego, z 12 XII 1858. Cyt. za: C. Norwid, Pisma wszystkie, t. 8: Listy 1839-1861, s. 550-551 (Metryki i objaśnienia). 
wszystkich pismach krajowych będace [...]"27. Trzy elementy znaczeniowe w cytowanych fragmentach są dla poety istotne: długi staż autorski, rozproszenie dorobku oraz jego rozlokowanie po „wszystkich” periodykach w kraju. W listach towarzyszacych inicjatywie Zaleskiego nie przedstawia więc Norwid siebie jako pisarza niedrukowanego. Mimo że wspomina również o utworach, które utknęły w redakcjach, eksponuje wszelako te opublikowane. Podkreśla swoją obecność, jeśli nie wszechobecność na łamach prasy, a stąd i w czasie bieżacym.

Utrwalony w listach obraz autora „rozrzuconych” poezji nie powstał ad hoc, z potrzeby chwili. Znajdziemy go również w dedykacji do utworu Psalmów-psalm jako „Pieśni społecznej” poszyt trzeci z 1850 roku, zamykającego „myśli całokształt”, której poszczególne cząstki „wichry” wyrywały Norwidowi „spod ręki” (DW-4 75). Obraz ten pojawia się także w przypisie (gwiazdkowym) do wspomnianego poematu, przekazanego Augustowi Cieszkowskiemu. Co ciekawe, Norwid odnosi się tam do idei tomu zbiorowego:

Nie było mi nigdy tak pomyślnie, ażebym pisma moje, od lat tylu po różnych czasopismach rozrzucone, wydał razem, czym mógłbym (jak to inni czynią) przyzwyczaić do mowy o ciemność oskarżanej - bo już dziś mi niełatwo innej mowy się uczyć. [DW-4 88]

Zarzuty o „ciemność” zostały powiązane $z$ brakiem obszerniejszego wydania dzieł Norwidowych, które pozwoliłoby czytelnikom oswoić się ze stylem autora. Prezentacja idiomu pisarskiego miała być ogólnie przyjętym celem takich edycji.

W cytowanym przypisie Norwid uznaje celowość tego rodzaju przedsięwzięcia edytorskiego ze względu na recepcję. Wydałby też swój tom poezji - ,jak to inni czynią” - gdyby sprzyjały okoliczności. Ale przecież nie sprzyjały nigdy. „Dzisiejszy” Psalmów-psalm jest czwartym ogniwem „pieśni”, poprzedzonym przez Wigilię, Pieśni społecznej cztery stron i Trzy pytania, z których tylko dwa pierwsze trafiły do druku bezpośrednio po wyjściu spod pióra poety, w dodatku każde $z$ osobna.

Listy z 1858 i początku 1859 roku pozwalają zauważyć radykalizację podejścia Norwida do kwestii zbiorowego tomu. Otóż kilkakrotnie sformułował w nich myśl, że taka edycja nie jest sprawą autora, lecz obowiązkiem społecznym. W związku z tym on sam nawet nie musiał się poczuwać do wdzięczności wobec inicjatorów przedsięwzięcia. Jeśli się poczuwał, to wiedziony zwykłym ludzkim odruchem. Zgłaszał też obiekcje do pomocy zaoferowanej mu przez rodzonego brata: „szwank czyni sobie, rzeczy, prawdzie, ktokolwiek czyni co prywatnymi drogi, jeźli to powinno było publicznymi robić się!” (DW-11 292). Uznając edycję zbiorową za wspólnotowy obowiązek względem twórcy, miał autor Quidama zapewne w polu widzenia inicjatywy podobne do tej Antoniego Zaleskiego. W roku 1841 Edward Raczyński wydał dwa tomy Poezji Józefa Bohdana Zaleskiego. W przedmowie dowiadujemy się o popularności „wieszcza” wśród czytelników, pozostającej w sprzeczności ze stosunkiem autora do własnego dzieła. Musiała się pojawić „znakomita Polka”, by czytelnicy mogli poznać twórczość Józefa Bohdana Zaleskiego „w całej ozdobie”:

27 C. Norwid: list do M. Trębickiej, z czerwca [?] 1858. DW-11 226; list do A. Zaleskiego, sprzed 13 VIII 1858. DW-11 242; list do M. Kleczkowskiego, z 13 VIII 1858. DW-11 245; list do J. I. Kraszewskiego, z listopada-grudnia 1858. DW-11 280; list do T. Lenartowicza, ze stycznia 1859. DW-11 292. 
On przecież przez skromność mało się udzielał, i nawet poezje, które dziś na widok publiczny wychodzą, byłyby jeszcze długo, długo w tece jego spoczywały, a może kiedyś i zaginęły, gdyby głos znakomitej Polki nie był ich wyrwał niejako $z$ więzienia. Przysłane na moje ręce, wydaję na świat, jako ozdobę literatury naszej w tym mocnym przekonaniu, że czarowny ich dźwięk u niejednego z czytelników naszych ukołysze na chwilę przynajmniej czarne troski lub podwyższy radość i nadzieję ${ }^{28}$.

Również Lenartowicz kobiecie zawdzięczał wydanie warszawskie swoich poezji w 1858 roku $^{29}$. Można odnieść wrażenie, że i Antoni Zaleski proponując Norwidowi zebranie jego poezji, ukrył własny udział finansowy w przedsięwzięciu, wymyślając jakąś hojną damę z Litwy, gotową wziąć na siebie koszt edycji. Anonimowa donatorka bardziej przystawała do roli reprezentantki społeczeństwa świadomego swoich obowiązków względem poety aniżeli przyjaciel.

Zestawienie listów poruszajacych wątek wydania zbiorowego pozwala odnotować to, co się w nich powtarza, ale zobaczyć też, jak myśl piszącego ewoluuje. Nawiązując do propozycji Antoniego Zaleskiego z lata 1858, Norwid ogląda planowany tom od strony czytelników. Nie wątpi, że tacy by się znaleźli i że lektura przyniosłaby im pożytek poznawczy. Pisze w liście do przyjaciela:

nie byłoby niekorzystnym, aby publiczność miała przed oczyma ciag jakiejkolwiek pracy przerywanej biegiem wypadków, które całymi narodami trzęsły, pokoleniami rzucały z kraju w kraj - mogłaby wtedy, ciąg takiej pieśni podruzgotanej rozpatrując, nauczyć się rozeznawania, co jest pracą ducha walczącego, a co pisaniem atramentem. [DW-11 242]

Co dawniej autor określał jako poezje „rozrzucone”, w liście cytowanym nazwał „pieśnią podruzgotaną”, zaniedbując zresztą metaforyczną zgodność obu członów formuły i polemizując z Mickiewiczowską „pieśnią gminną”, która zawsze „ujdzie cało”. Odbiorca napotykający wcześniej jedynie odpryski „pracy przerywanej”, nie miał szansy odróżnić intencji autorskiej od destrukcyjnego piętna „biegu wypadków”. Tom zbiorowy nie służyłby więc odbudowaniu dzieła „podruzgotanego”, ale odsłaniałby przed czytelnikiem obraz ponawianych - mimo przeszkód - zmagań twórczych autora. Jego pracę, lecz nie osobę. Swój przypadek traktował Norwid jako pouczające exemplum, nie zaś jako własne nieszczęście.

Perspektywę autorska przedstawił piszący we wspomnianym liście pobieżnie. Ustalał zakres swoich praw: chciał poprzedzić zebrana zawartość tomu „przemową”, zastrzegał też konieczność „małych sprostowań”. Po stronie autora bowiem kontakt Z „podruzgotaną” twórczością w pełniejszej odsłonie nie zmieniał zgoła niczego: „Nie uważałbym za poetę pisarza, który by w ciagu prac swych miał co do retraktowania, ale pewna ogółu korekta należy się zawsze autorowi” (DW-11 242). Poznawczo zyskiwał na wydaniu zbiorowym jedynie czytelnik. Samowiedza twórcy sprawiała wrażenie od dawna mocno ugruntowanej i nieweryfikowalnej. Czytamy dalej w tym samym liście:

za cały wieniec mój poczytuję sobie, iż nic dla nikogo osobiście ani dla druku nie pisałem, ani za pieniądze drukowałem, ani żadnych łatwości pozycji, stosunków, koteriów itd. nie używałem - pieśń mą, 
jakkolwiek połamana jest, tym samym właśnie całą mając, iż atramentem mało pisaną była. [DW11 242-243]

Wyznanie to można by potraktować jako manifest autorskiej wewnątrzsterowności. W ostatnim liście do Antoniego Zaleskiego w wiadomej sprawie - z połowy grudnia 1858, w liście-,testamencie”30, kwestia autorska przedstawiała się już skrajnie inaczej. Norwid nie tylko cedował na adresata napisanie wstępu, ale zobowiazywał go ponadto do zawarcia tam myśli o znaczeniu wydania zbiorowego dla poety. Jak czytamy we wspomnianym liście:

po pewnej dobie pracy poeta i artysta, nie widzac zbiorowego obrazu swej rzeczy względem publiczności, nie jest $w$ stanie dalej trwać, $i$ tym sposobem zabiera się człowiekowi więcej niż utwory, bo twórczość. [DW-11 285]

Rozważając tom zbiorowy od strony korzyści dla czytelnika, Norwid dostrzegał szansę uobecnienia autora jako spoiwa „pieśni podruzgotanej”, w liście testamentowym okazywało się, że „zbiorowy obraz” jest potrzebny samemu artyście jako warunek kontynuowania pracy twórczej. Jeśli przez pryzmat zacytowanego zdania spojrzeć na Brockhausowską edycję Poezji i jej następstwa, to należałoby wnioskować, iż do napisania Vade-mecum pobudziła Norwida nie sama możliwość kontynuacji współpracy z lipskim wydawnictwem, lecz właśnie „zbiorowy obraz”, który wyłonił się z Poezji w sposób inspirujący dla samego autora.

\section{Edycja lipska}

Gomulicki podkreślał, że Poezje Norwida z 1863 roku nie wywołały żadnych recenzji, i obciążał tym sumienie nieżyczliwych krytyków. Ale powód braku rezonansu mógł być całkiem inny, jeśli się pominie nawet okoliczności nie sprzyjające zainteresowaniu literatura $\mathrm{w}$ czasie powstania styczniowego i w latach następnych. Wydania Brockhausowskie, ujęte w serię „Biblioteki Pisarzy Polskich”, zazwyczaj nie pobudzały recenzentów do chwytania za pióro. Seria była tak pomyślana, również co do oprawy, że nie potrzebowała rekomendacji krytyków w drodze do publiczności $^{31}$. Sięgając po kolejne tomy serii, wywiązywano się z powinności patriotycznej. W ramach „Biblioteki” ukazywały się bowiem reedycje dzieł autorów o znanych nazwiskach bądź teksty ważne jako świadectwo polskich doświadczeń doby rozbiorowej. Pierwszy tom z 1860 roku wypełniły Poezje Stefana Garczyńskiego. „Wydawca” unosił się nad dziełem bezsprzecznie wybitnego, lecz „smutnym przeznaczeniem losu" zapomnianego poety ${ }^{32}$. Edycja lipska przywracała mu należne miejsce na Parnasie, potwierdzone swego czasu autorytetem Mickiewicza:

Zob. C. N orwid, Testament literacki z 1858 r. Wydał i objaśnił T. Przy p k ow s ki. Kraków 1935. Wynika to z inseratu zamieszczonego Katalogu ksiażek polskich nowych, znajdujacych się u F. A. Brockhausa w Lipsku, który cytował B. Zakrzew s ki w artykule Mickiewicz i wydawnictwa Brockhausa („Pamiętnik Literacki” 1998, z. 4). W ramach „Biblioteki” miały się ukazywać „dzieła autorów znanych zaszczytnie i zasłużonych w literaturze polskiej, a których te utwory albo nie istnieja w całkowitym zbiorze, albo zupełnie zostały wyczerpane w handlu ksieggarskim” (cyt. za: ibidem, s. 187-188).

F. A. Brockhaus, przedmowa w: S. Garczyński, Poezje. Lipsk 1860, s. V. 
Mistrzowi to wielkiemu na chwałę i pamiątkę poświęcam to nowe wydanie jego tworów. Niechaj wędrówka onych po świecie narodowym naprawi niesprawiedliwość losu: niech to imię: S te fa n G a rczyński - zabłyśnie powtórnie ponad krainami, dla których działał; niech zabłyśnie jako meteor kraju polskiego w obłokach Parnasu, na tronie sławy, na dumę i zaszczyt rodaków ${ }^{33}$.

Ze wstępu w inicjalnym tomie serii można wnosić, że każdy kolejny miał zadanie analogiczne: uobecnić autorów tworzacych polski Parnas.

Watłą recepcję Poezji Norwida warto by powiązać $z$ inną jeszcze okolicznością niż dotąd rozważane. W „Dzienniku Literackim” z 1862 roku oskarżono wydawnictwo Brockhausa o żerowanie na polskich autorach i ich rodzinach. Chodziło o samowolne wydanie Pism Mickiewicza. Publicznie żądano od oficyny, by uzyskała pozwolenie na druk od spadkobierców i stosowne oświadczenie dołączyła do edycji. $\mathrm{W}$ razie odmowy:

nikt z Polaków tego wydania nabywać nie powinien, ani też żaden księgarz je sprzedawać.

Pisma zaś wszystkie polskie upraszamy, aby podobną przestrogę powtórzyły w swoich kolumnach ${ }^{34}$.

Niewykluczone, że wezwanie do bojkotu odniosło praktyczny skutek i objęło nie tylko tomy Mickiewiczowskie. W każdym razie Brockhaus, obawiając się szkodliwych dla siebie następstw awantury, przesłał odpowiedź na artykuł w lwowskim piśmie. Zapewniał o szlachetnych celach, dla których powołano „Bibliotekę Pisarzy Polskich”, miała ona „obznajomić nie tylko publiczność warstw wyższych, ale i niskich z najlepszymi i najzbawienniejszymi utworami polskiej literatury, przy poprawnym i ozdobnym ich wydaniu oraz najniższych cenach"35.

Norwid podpisał umowę $\mathrm{z}$ oficyną Brockhausa, otrzymał honorarium. Jego Poezje, wydane jako tom 21 „Biblioteki”, dołączyły do Pism Juliusza Słowackiego (t. 2-5), Obrazków caryzmu Jakuba Gordona (t. 6), Pamiętnika historycznego o wyprawie partyzanckiej do Polski $w$ roku 1833 Karola Borkowskiego (t. 7), Pism Adama Mickiewicza (t. 8-12) i Pism Michała Czajkowskiego (t. 13-20). Jak widać, niekoniecznie trzeba było tworzyć poezję, żeby znaleźć się w gronie autorów rekomendowanych przez „Bibliotekę”. Oprócz „wieszczów” trafiali się pamiętnikarze. Nie w każdym tomie odzywał się też egzaltowany „Wydawca”. Memuary Gordona zostały poprzedzone przedrukiem recenzji Lucjana Siemieńskiego. Historię wspomnieniowa Borkowskiego zapowiadały dwie przedmowy autorskie, do pierwszego i drugiego - aktualnego - wydania. Obszerne wstępy towarzyszyły również utworom Czajkowskiego (Wernyhora, Kirdżali, Powieści kozackie i gawędy, Owruczanin, Stefan Czarniecki, Hetman Ukrainy), „przejrzanym i poprawionym”. Przypominając czytelnikom swego Wernyhorę, pisarz opowiadał, że „myśl o Kozaczyźnie”, która ukierunkowała jego życie przeszło 30 lat temu, odziedziczył po przodkach:

moje marzenie przeobrażało się w teorię, w system, którego ja byłem pisarzem i ja musiałem być wykonawcą; bo nikt się nie znalazł, kto by się chciał podjąc tej pracy dla Kozaczyzny - dla Polski.

Rzuciłem w świat polski powieści kozackie, Wernyhorę, Ukrainki, Hetmana Ukrainy i inne pisma tegoż samego ducha, dążące do tego samego celu; i po tym moim programacie udałem się na Wschód ${ }^{36}$.

Ibidem, s. VI.

Wydania Brockhausa. „Dziennik Literacki” 1862, nr 32, s. 256.

Rozprawa z księgarzem lipskim, s. 336.

36 M. C zajk ow s ki, Dnia 10 sierpnia 1861 roku. Na statku rosyjskim Chersonez naprzeciw Świętej 
W „systemie” zawierał się klucz do powikłanej, „dziwnej” biografii Czajkowskiego ${ }^{37}$, stanowiącej z kolei niezbędny kontekst interpretacyjny dla kozackich powieści.

Norwid, prawie najmłodszy wśród autorów „Biblioteki” (później urodził się tylko Maksymilian Jatowt używający pseudonimu Jakub Gordon), nie opatrzył swoich Poezji przedmową. Gdyby taką sporządził, znalazłaby się w niej zapewne informacja, że w prezentowanym zbiorze większa część utworów ma charakter pierwodruku. Jest to ewenement w serii, biorąc pod uwage pozostałe 20 tomów. Wydawałoby się, że przedmowa w tej sytuacji była manewrem ze wszech miar pożądanym. Dlaczego Norwid jej nie przygotował, jak czynili wszyscy żyjący autorzy tomów „Biblioteki”? Nic na ten temat nie wiemy. Może zabrakło mu czasu, a może nie chciał pisać tekstu, który trąciłby „atramentem”? A może dlatego, że w Poezjach nie brak wstępów organicznie związanych z poszczególnymi utworami: Próby. (Jako wstęp do „Zarysów obyczajowych pięciu”), Do A. Z. - dedykacja przed Bransoletka, Do krytyków przed Krakusem, wstęp do Epimenidesa, Do Z. K. przed Quidamem. Zreszta, jeśli inicjalnym Próbom przyjrzeć się - wbrew podtytułowi - w kontekście całego zbioru, problem wstępu przestanie, na dobrą sprawę, doskwierać ${ }^{38}$.

Wiersza tego Norwid nie opatrzył datą, co nie jest w Poezjach regułą. Edytorom nie udało się jej ustalić ponad wszelką wątpliwość. Rozważali rok 1856, lecz też lata: 1860, 1861-1862. Jeśli przyjąć tę ostatnią hipotezę, Próby należałyby do grupy utworów najbliższych czasowo pracy nad „architektura” tomu lipskiego. Autor Poezji nie zdążyłby się więc zanadto oddalić od autora wspomnianego wiersza. Łączyłaby ich nie tylko więź intelektualna, ale i bliskość wynikająca ze wspólnego horyzontu doświadczeń. Rzeczą niewątpliwą jest natomiast, że wyznaczenie Próbom miejsca inicjalnego stanowi wyrazisty gest autorecepcyjny.

Pierwszy wiersz zawiera idee i obrazy, które będa wracały w innych utworach zbiorowego wydania. W toku lektury Poezji czytelnik nauczy się także śledzić motywikę harficzna. Nie przeoczy jej na pewno, bo „harfę” zawiera tytuł anonsujący zestaw wierszy lirycznych i okolicznościowych. Kilkakrotnie pojawia się w inicjalnych Próbach, jest więcej niż rekwizytem w Krakusie. W ostatnim wierszu zbioru - Pol$k a-$ zobaczymy dwóch harfiarzy uczestniczacych w osobliwym agonie.

Nierówny pojedynek między poetą ulaurowanym a poetą wzgardzonym przez słuchaczy wygląda wręcz na ilustrację do końcowych partii Prób:

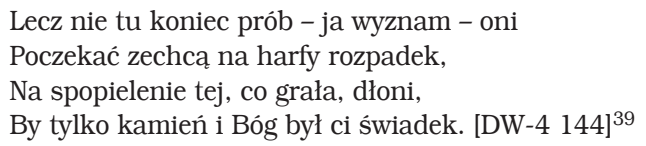

Góry (Mont. Athos). Przedmowa w: Wernyhora. Wieszcz ukraiński. Powieść historyczna z roku 1768. Wyd. 3, przejrz. i popr. Lipsk 1862, s. VII.

M. C z aj k ow s ki był autorem dzieła biograficznego Dziwne życia Polaków i Polek (Lipsk 1900). W Uwagach edytorskich do Prób (DW-4 322) uwzględnia się ewentualność, że wedle intencji autorskiej wiersz był także wstępem do całości. Obszerny artykuł poświęcił Próbom M. B u ś (Uwagi o „Próbach” Norwida. „Studia Norwidiana” t. 19 〈2001〉), wyzwalając „piękny” ów wiersz z ograniczających przystęp do nich związków z Zarysami obyczajowymi.

Fragmentowi temu zdają się odbrzmiewać wersy z Quidama C. Norwida (w: Pisma wszystkie, t. 3: Poematy, s. 219):

A potem $\mathrm{z}$ dziwnym na twarzy wyrazem

Ku arfie poszedł czerwono okrytej, http://rcin.org.pl 
W „harfy rozpadku” daje się usłyszeć dalekie echo „pieśni podruzgotanej” z listu do Antoniego Zaleskiego. Jest też ów „harfy rozpadek” odwróceniem motywu porzucania lutni, ciskania bardonu - znanego z twórczości poetów starszego pokolenia.

Obraz oceanicznej przestrzeni „bez końca” (DW-4 142) z inicjalnego wiersza dopełnia się oceanem z „legendy” Cywilizacja, a „miejska” strofa zapowiada Quidama, którego bohater na początku poematu staje u bram Rzymu.

Wiersze pierwszy i ostatni tworzą rodzaj metatekstowej ramy zbioru. Sama ich pozycja nakazuje lekture pod kątem akcentów autorecepcyjnych ${ }^{40}$. Jeden $z$ nich polega na wskazaniu harfy jako atrybutu poety - autora Poezji. Tak oto Norwid sięgał po wypróbowany przez innych twórców sposób autoprezentacji czy autodefinicji. W najbliższym otoczeniu służył mu za punkt odniesienia Lenartowicz ze swoją lirenką. Harfa, która czytelnik napotyka w Poezjach po wielekroć i w różnych odsłonach, była łącznikiem $z$ tradycją psalmiczną, a więc i z Krasińskim, lecz aktualizowała też więź ze Słowackim ${ }^{41}$. Twórczość ich obu zajmowała Norwida w kontekście zagadnienia „stanowiska poety w społeczeństwie”, podnoszonego w prelekcjach z 1860 roku $^{42}$. Wydane rok później wykłady były swego rodzaju wstępem do Poezji.

Drugie istotne $-z$ uwagi na autorecepcje - zagadnienie stanowi relacja między poezją a jej twórca. Kiedy Norwid pisał w liście o „pieśni podruzgotanej”, wiązał ją z kataklizmami historycznymi rewolucyjnych lat czterdziestych XIX wieku. Planowany w 1858 roku zbiór miał pokazać czytelnikom, że destrukcja nie dosięgła podmiotowości autorskiej. W świetle wstępnego utworu z lipskiego tomu inaczej rzecz się prezentuje. Poezja „żywa” rodzi się w morderczych, a przy tym i poniżających próbach, które wystawiają na szwank i widok całe człowieczeństwo poety, w wymiarze cielesnym i duchowym:

Jeśli więc w łunach tych ciebie zobaczę Nieodmienionym i $z$ gwiazdą na czole, Której ci z włosem nie wydrą rozpacze; [DW-4 144]

Przemawia do wyobraźni brutalność gestu wydzierania włosów z głowy (o ileż mocniejsze jest wydzieranie od zleksykalizowanego wyrywania) i jego groteskowość w zestawieniu $\mathrm{z}$,gwiazdą na czole”, przejętą od autora Nie-Boskiej komedii. Podobnie drugi harfiarz z Polki, nim zacznie pieśń pochwalną, musi obnażyć przed słuchaczami swoją bezsilność:

\footnotetext{
Gdy drugi wszedł śpiewak stroną drugą, Harfę wlekąc swą - czy zniechęcenie, Czy może był dnia onego chory? -43
}

Mówiąc „gdybyż się serce stało głazem Miałoby taki kształt!" [...].

40 W perspektywie autorecepcyjnej można by odczytać też np. „pierwiastki klasyczne” w Poezjach, omówione przez R. Fi e gu th a (Zaproszenie do "Quidama”. Portret poematu Cypriana Norwida. Kraków 2014, s. 217-230).

41 Harfe jako motyw spajający Poezje omawiam szerzej w artykule Pożegnania z romantyzmem (s. 141-142). Lektura według klucza harfy prowadzi także do Krasińskiego. O relacji Norwid-Krasiński pisał obszernie Fi g g th (op. cit.).

42 C. Norwi i, O Juliuszu Stowackim. W: Pisma wszystkie, t. 6: Proza, cz. 1, s. 408. Twórczość obu romantyków przemyślał Norwid w związku z pytaniem: „co jest poeta?”, na użytek prelekcji wygłoszonych w 1860 roku. 
Próby zaczynają się modlitewnie: „Błogosławione pieśni malinowe [...]”, „Błogosławiona jest gorycz wiośniana [...]”, „Błogosławione jest i obce dalej [...]” (DW-4 141), itd. Ich czytanie przychodzi bez trudu. Oddech łatwo zestraja się $z$ tokiem wiersza. Nie tylko za sprawą układu wersyfikacyjnego, ale też dlatego, że w pierwszej strofie znajdujemy takie słowa: „Odetchnać dosyć, by odetchnąc Bogiem!” (DW-4 141). Czytamy „Odetchnąć”, oddychając. Odetchnięcie przynosi ulgę. Dźwiękonaśladowcza zbitka głosek w powtórzonym słowie „odetchnać” pozwala zaznać odetchnięcia, poczuć na własnym podniebieniu uwalniane $z$ płuc powietrze.

Z kolei po dziewiątym „błogosławieństwie”: „Błogosławione wszystko to - i nie to -" (DW-4 143), oddech ulega zmąceniu:

Ale czy będę błogosławić tobie,

O! miasto wielkie - serc i kwiatów grobie? - [DW-4 143]

W mieście oddech nie łączy z Bogiem. Oddychanie nie jest tym samym, co odetchnięcie: „oddychając, cudze chłoniesz tchnienia [...]” (DW-4 143). W mieście wdychasz cudze oddechy. Dusisz się nimi, co uzmysławia natłok dźwiękonaśladowczych głosek.

Autor Prób w pierwszej ich części dowodzi, że mógłby tworzyć „pieśni malinowe”, „pieśni kalinowe” (DW-4 141) (jak autor Lirenki), czerpiąc inspirację z natury. Problem polega jednak na tym, iż wyzwaniem dla współczesnego poety jest „wielkie miasto” (odwrotność „małego światka” Lenartowicza). W Poezjach strofa ta zdaje się anonsować Guidama, najokazalszy element w lipskim tomie. Do „wielkiego miasta” przybywa młody bohater poematu i kończy życiową próbę przypadkową, miejską śmiercią.

Gdyby Norwid opublikował swój rzymski poemat osobno, znaczyłby on przede wszystkim przez odniesienie do twórczości Krasińskiego. Jako element Poezji ujawnia najpierw związki $z$ otoczeniem tekstowym, wynikającym $\mathrm{z}$ lokalizacji w edycji Brockhausowskiej.

\author{
Abstract \\ ELŻBIETA DĄBROWICZ University of Białystok \\ ORCID: 0000-0001-7284-2248 \\ CYPRIAN NORWID'S "POEZJE" ("POETRY", 1863) \\ AS TESTIMONY OF AUTORECEPTION
}

The article is devoted to a Leipzig edition of Cyprian Norwid's Poezje (Poetry, 1863) published by Friedrich Arnold Brockhaus. Editors of the poet's writings did not consider the volume to be an integral entity that should be included into the edition of Norwid's entire output. This decision, though understandable on the grounds of editorship, overshadows his most crucial publication achievement, also important from an autoreceptive perspective. Poezje (Poetry) is therefore the first edition of Norwid's collected poems that allowed him a confrontation with his own writing style and consideration of his own creative path. Poezje (Poetry), published as volume 21 of "Biblioteka Pisarzy Polskich" ("Library of Polish Writers"), defined its author as a mature writer, conscious of his vocation and workshop (indication to the harp as to a poet's attribute, to "great city"-a place of trial for a poet and poetry). It also seems reasonable that composing the collection offered Norwid a stimulus to new creative investigations which he realised in Vade-mecum. 